\title{
The Relationship between World Views of Rectors with Corporate Entrepreneurship and Strategic Management in Turkish Universities
}

\author{
Ata Özdemirci ${ }^{1}$, Esra Dinç Özcan ${ }^{1} \&$ Görkem İldaş \\ ${ }^{1}$ Faculty of Business Administration, Marmara University, Turkey \\ Correspondence: Ata Özdemirci, Faculty of Business Administration, Marmara University, Ressam Namık \\ İsmail Sokak, No. 1, Bahçelievler, 34180, İstanbul, Turkey. Tel: 90-212-507-9925. E-mail: \\ ataozdemirci@gmail.com
}

Received: November 9, 2013

Accepted: November 25, 2013 Online Published: December 18, 2013

doi:10.5539/ijbm.v9n1p149

URL: http://dx.doi.org/10.5539/ijbm.v9n1p149

\begin{abstract}
The main subject of this study is to examine the relationship between university rectors' political views personality traits and choice of strategy and corporate entrepreneurship. However, this study does not only investigate the relationships between the theoretical aspects of the cases, at the same time it is also important to demonstrate the political views of rectors which has many prejudices and assumptions about it because of the non-democratic appointment process of rectors in state universities in Turkey. The study also tries to picture strategy preferences and entrepreneurial behavior of state and private universities. A questionnaire consisting of 55 questions was prepared for the study, and all rectors of 105 state and 64 private universities in Turkey were asked to participate in the survey. The answers were obtained through face-to-face interviews and e-mail. 64 rectors participated in this survey, 7 responses were invalid. Our research offers several clear findings: Firstly, rectors are more liberal in universities that implement differentiation strategies. Secondly, normative rectors are distant to new business venturings. Thirdly, innovativeness is compatible with a differentiation strategy as has been revealed many times in pertinent literature. When we glance at additional findings of the survey, it attracts attention that foundation universities prefer administrators who are liberal in their world view, but more deliberate and normative in their business lives. Besides, it was observed that foundation universities use differentiation and focus strategies significantly more often than state universities, and that their levels of new business venturings are higher than those of state universities.
\end{abstract}

Keywords: university management, corporate entrepreneurship, strategic orientation, political views of rectors, personality traits

\section{Introduction}

University management is a comprehensive concept which includes issues such as determining the strategic direction of the universities, coordinating production processes of knowledge and service, running marketing and public relation activities, making effective use of intellectual capital, sourcing processes, or cooperation with stakeholders outside the University.

In fact, there isn't much difference between university management and company management. Cases such as strategic decision-making mechanisms, growth and downsizing decisions, investments and marketing policies are applied in universities too. Still, it would be invalid to assess a university manager as a CEO of company in a study on the management of the University. The first problem is to address the issue comparability whether the state and private universities can compare in the same way with the profit-oriented organizations. The second problem to be considered is the authority which has taken responsibility and authorization. When we look at the process of appointment of rectors, one of the arguments which makes the academic and politic agenda too busy is whether the rectors possess the freedom of decision-making or not.

To start with the first problem: offering new products and services while following an aggressive strategy and high-risk projects implementation can also be applied to universities. Competition between universities does not have to be only related to profitability. Universities are competitive in many fields such as (1) to be preferred by better students, (2) being more successful in scientific and technologic contributions than the others, (3) creating more projects, (4) publishing and broadcasting more, (5) and having better academic staff and cooperating with 
businesses. At the same time, expensive MBA and certificate programs started by both the state and private universities reveal that the dimension of the material part of the race is not trivial at all.

The second problem is: When it comes to the examination of the strategic choices and the level of corporate entrepreneurship of universities-whether it is related to the political views of top managers or not-as well as their rectors' character traits, the forms of autonomy and the appointment process of rectors of state universities cannot be ignored. Such a study should first go about the issue of the autonomy of the university management.

One of the main building blocks of an ideal university can be specified as autonomy. Autonomy is one of the most discussed topics not having reached the unity of definition. The Magna Charta Universitatum that the rectors of the European Universities signed in Bologna, Italy (18 September 1988), denotes the autonomy of the universities as follows: (Aktan, 2007).

"Universities are organized in different ways as geographical location and historical heritage of autonomous institutions produce and develop culture through education and research. To be ready for the needs of the world which the universities act in, depends on research and teaching activities independent from all the other economical and political forces and beside this independence of the spiritual and intellectual aspects."

It is obvious that universities in Turkey are not autonomous, but directly or indirectly subject to the intervention of the Board of Higher Education. However, nowadays the main discussion is carried out through the appointment type of rectors rather than the freedom of scientific activities, making their student choices or giving financial or strategic decisions.

At this point, it is appropriate to give a brief overview about how the rectors are selected in Turkey. Whilst rectors are appointed by the board of trustees in foundation universities, in state universities rectors are appointed by the president, after a perfunctory election, without looking at the number of votes received. This system was put into constitution as an ideological insurance to prevent an appointment of a rector with a world view that is incompatible with the dominant ideology.

However, before analyzing the political views of rectors, it is necessary to give a little reminder about the concept of libertarianism. The matter that whether seculars or the conservatives currently in power are more liberal is highly controversial in Turkey, because the concepts of rightists and leftists in Turkey don't show full compliance with their international counterparts. In elections, for example, right-wing parties could use a variety of leftist discourse, whereas left-wing parties, in order to protect the republic, might display a conservative attitude in many areas. In other words, the left can exhibit repressive and conservative attitudes, while the conservative school may be prone to display libertarian attitudes in many issues in Turkey. However, this liberal attitude changes when it comes to concepts such as dating, freedom of the internet, conflicting views of the world with religious people. In some cases, members of the conservatives who defend a liberal discourse turn into strict moralists. The subject of curiosity during our research was if today's rectors are also stuck in this dilemma or not-especially when looking at the pattern of the appointment process of the rectors, and considering they were appointed by a conservative president.

In this study, as a main subject, the relationship between rectors' political views-personality traits and choice of strategy-corporate entrepreneurship is examined. However, this study does not only investigate the relationship between the theoretical aspects of the cases, at the same time it is also important to demonstrate political views of rectors which has many prejudices and assumptions about it.

\section{Literature Review and Hypothesis}

\subsection{Universities and Corporate Entrepreneurship}

Contemporary entrepreneurship research started with economist Joseph Schumpeter's studies (1883-1950). Schumpeter defined entrepreneurship as old products or production replaced with new ones or destroyed "creative destruction" process. Schumpeter finds this process positive because innovations represent product or process development and consequently attract the attention of buyers and creating more economic business. (Barringer \& Bluedorn, 1999).

Corporate entrepreneurship is a constantly developing research area. Researchers use many terms in order to determine different specialties of corporate entrepreneurship. These can be designated as: intrapreneurship (Kuratko, Montagno, \& Hornsby, 1990), internal corporate entrepreneurship (Schollhammer, 1982), corporate ventures (Ellis \& Taylor, 1987), new ventures (Roberts, 1980), and internal corporate venturing (Burgelman, 1984).

There are also different assumptions in the literature on corporate entrepreneurship (Gautam \& Verma, 1997). 
For example, Popescu \& Lache (2009) suggested that there are some features of entrepreneurship that are generally accepted. According to them, entrepreneurship features can be determined as: emergence of new ideas and solutions; the implementation of socio-economic conditions; obtaining useful results; taking risks. According to Zahra (1991), corporate entrepreneurship, in order to increase the rate of an organization's profit and enhance the company's competitive position or policies of strategic renewal, refers to the process of creating new jobs in the well-established companies. Burgelman (1984) conceptualizes corporate entrepreneurship as a process of "extending the firm's domain of competence and corresponding opportunity set through internally generated new resource combinations". Here, the term "new combinations" is used as a synonym for "innovations", which is used by Schumpeter. Thus, corporate entrepreneurship is understood as creating new industries or altering the balance of competition that make use of improvements and innovations in firms, developing the firm's competitive advantage effort.

The main idea is that corporate entrepreneurship is a behavioral concept and that all firms are involved in the process that can be perceived as if on a scale of conservatives to entrepreneurs. Entrepreneurial firms take risks, are proactive and innovative. On the contrary, conservative companies don't take risks, are less innovative, and adopt a "let's wait and see" philosophy. The location of firms in this scale is shown as the density of entrepreneurship. One of the main themes reoccurring in the literature on corporate entrepreneurship is that a firm's level of entrepreneurship is affected by external or internal elements. Looking at external factors, in comparison to stable environments, companies around the more variable and intensely competitive environments are proactive, more innovative, and willing to take risks. (Miller \& Friesen, 1982; Miller \& Friesen, 1983; Miller, 1987; Covin \& Slevin, 1989; Güth \& Ginsberg, 1990; Covin \& Slevin, 1991; Zahra, 1991; Antoncic \& Hisrich, 2001; Antoncic \& Hisrich, 2004). In terms of the internal elements, the organic business structure; management support, reward system, autonomy, HR systems, and innovative climate and culture will positively affect the corporate entrepreneurship. (Kanter, 1985; Zahra, 1986; Covin \& Slevin, 1988, 1991; Stevenson \& Jarillo, 1990; Kuratko et al., 1990; Zahra, 1991; Russell \& Russell, 1992; Naman \& Slevin, 1993; Hornsby, Naffziger, Kuratko \& Montagno, 1993; Zahra, Jennings \& Kuratko, 1999; Antoncic \& Hisrich, 2001; 2004).

"Corporate entrepreneurship" is associated with different organizational facts and events: When (1) an established organization enters a new business, (2) an individual or individuals support new product ideas in the context of an institution, (3) an entrepreneurial philosophy affects the appearance and functions of an organization. These events are not alternatives to each other internally, but can exist within the organization's entrepreneurial activities in different dimensions (Covin \& Miles, 1999).

It is possible to discuss the corporate entrepreneurship as the summary of innovations, risk taking, and proactiveness features (Miller, 1983; Covin \& Slevin, 1989). These activities usually aim at improving the innovation, adaptation, and fast response characteristics of the strategic features to be able to counteract the changes in the firm's environment.

The concepts of innovation, proactiveness, risk taking, renewal, and venturing are vital for corporate entrepreneurship. Innovation denotes the ability of the company to create new products and to introduce these new products to the market. It also means the company's commitment to the innovation of processes and organization (Zahra, 1993). Innovation forms new products, processes, and organizational systems-these give the company many advantages to surpass the competitors. Innovation also means reviewing the data of the company's resources which provides an opportunity to develop new competitive approaches (Zahra \& Garvis, 2000). Proactiveness means to follow good market opportunities for the company and to be the first implementer of innovations in the industry. Risk taking is defined as a company's support to the innovative projects, although financial gains from these activities are uncertain. Entrepreneurial activities also can renew well-established firms (Stopford \& Baden-Fuller, 1994). Renewal can usually be developed with innovative and venturing activities (Guth \& Ginsberg, 1990). This provides access to different abilities, competencies and resources for the companies. Venturing activities, entering new foreign markets or expanding in the market emphasizes the creation of new business areas. Therefore, a firm can review its own business areas by entering new economy areas or foreign markets. Thus, the company will learn about resources used in different places and the difference between these resources (Zahra \& Garvis, 2000).

Today, one of the issues in entrepreneurship literature is university entrepreneurship-particularly, the adaptation of study programs to the socio-economic needs, differentiation, increasing the attractiveness, developing academic research, allocating more capital to research, gathering different financial resources, effective use of resources and participation in public projects are current issues of universities everywhere. A systematic approach to these problems inspires the development of new models of universities with "entrepreneurial 
management". The university's entrepreneurial management can be defined as being open to new ideas to improve the performance of the management of the university to be able to constantly adapt to the new needs (Popescu \& Lache, 2009). The openness of a university's administration to the suggestions from employees, its support of new projects, ideas and bold actions, and empowering employees to take initiative are vital at this point.

The entrepreneurial dimension of the university administration is developed as a normal reaction versus the external environment and competitive dynamics like educational services, research needs, quality standards, reduction of available financing and so on. Especially after 1990, the rate of meeting these demands has become the most important condition of the existence of universities (Popescu \& Lache, 2009).

The growing influence of business venture models as an institutional objective created pressure for change in many countries over the years. Also, the expectations from universities vary as well as their performances. In the 1980s and 1990s, because of the increase in mass education, the relevant literature started to be more and more focused on organization and management of higher education institutions. The idea of entrepreneur universities that should be organized and managed as business enterprises influenced the normative debate on organization and leadership in higher education (Bleikliea \& Kogan, 2007).

One of the researchers who have conducted very important studies in the field of university entrepreneurship, Burton Clark (2004), stated five must-have features of entrepreneurial universities:

- A strong central steering core to embrace management groups and academics;

- An expanded development periphery involving a growth of units that reaches out beyond the traditional areas of the university;

- Diversity in the funding base, not only by making use of government funding but of a wide variety of sources;

- A stimulated academic heartland with academics committed to the entrepreneurial concept;

- An integrated entrepreneurial culture defined in terms of common commitment to change.

One of the competent authors in this area, Etzkowitz (2004), stated various elements within the concept of the entrepreneurial university to focus on as: (1) knowledge capital, (2) checking the government and industry's commitment to each other, (3) independence from any custom field, (4) managing the tension between independence and being dependent, (5) embodying reflexivity, (6) and constantly refreshing the internal structure of the hybrid management strategies.

An entrepreneurial university is an organization that works actively on renewing its work. To be in a better position in the future, it tries to make significant changes in corporate identity and strives to become a key actor (Clark, 1998). Universities in developed countries seem to be more and more entrepreneurial. Since the early 1980s, U.S. universities have significantly increased their entrepreneurial activity in many areas: patenting and licensing, science parks, university administration, and founding the investments projects. An increase in the universities' entrepreneurship in Europe can also be observed in this era (Rothaermel, 2007). Our study illustrates the level of corporate entrepreneurship in universities in Turkey. However, it should be noted that this picture, drawn by the rectors of the universities themselves, is perceptional. To reveal the true sense of the mechanisms of corporate entrepreneurship in universities, a much more comprehensive study is required.

\subsection{Universities and Strategic Orientation}

In the 1980s, developments all over the world affected the differentiation, the social sensitivity and the spread of transnational outlook, layout and administrative structures of the universities (Dill, 1992). Universities, which want to be successful in a competitive environment, have begun to make studies about strategy development.

Universities have been focusing on strategy formulation and planning issues for more than twenty years. Implementing the business approaches to higher education has been a great purpose for introducing the development of the strategic management skills for assisting universities to become more effective. George Keller's book "Academic Strategy" can be cited as an excellent example of this approach (Keller, 1983). According to Keller, a new era, which brings awareness of academic strategy, comes forward in America. In this book, Keller explores issues such as the management revolution in American higher education institutions or how institutions of higher education met strategic decision making. Subsequent authors started to work on the organizational characteristics of universities and tried to find how they affect strategic planning (Chaffee, 1985; 1989).

One of the essential studies on the strategic choice of higher education is Cameron's work on the different adaptation strategies. Cameron (1983) identifies domain defense, domain offense, and domain creation 
strategies in this study. According to Cameron, organizations that apply these strategies can provide a successful fit to the turbulent and competitive environment. His study also emphasizes the need to consider alternative strategies which focus on efficiency and innovation, although university administrators need to be conservative and efficiency-oriented.

According to Kotler \& Murphy (1981), the big universities must pay necessary attention to the strategic planning if they want to survive in troubled times. Unfortunately, most of the universities succeed in the operational sense, but they do not have sufficient capacity for strategic planning.

We think that strategic behaviors which the universities exhibit to be successful in the areas of competition mentioned above-to be preferred by better students, to beat their rivals at the scientific and technological contributions, making more projects, more broadcasting, having better academics, performing more cooperation with businesses- can be clearly classified with Porter's (1980) basic model, although it is claimed to be more complicated. The reason for choosing Porter's generic strategies model is that this classification is simple, easy to understand, and easily measurable. According to Porter, competitive strategies are a set of decisions and behaviors to provide a competitive advantage through possessed basic competences and to create values for customers in a certain market. These strategies are the basis of the competitive strategies an organization uses in order to prevent competitors in the industry. There are lots of strong and weak aspects of an organization in the face of its competitors. The most important issue in the competitive strategy is the position of the organization compared to its competitors in its market. There are three different competitive strategies which can be used to attain competitive advantages by organizations: differentiation, focus and cost leadership (Porter, 1980). Two or more of these competitive strategies can be applied in a business, factory or functional part at the same time.

The basis of a differentiation strategy (Porter, 1980) is the production of goods and services which will be regarded as unique in the sector of activity. When applied successfully, a differentiation strategy provides above-average returns for the company which prefers this strategy in the sector of activity. A differentiation strategy reduces the affection level of businesses through competitors' behaviors and provides stability in sales caused by loyalty of the customers to the company, its goods and services while at the same time having customers accept buying at a higher price. In universities, a differentiation strategy is applied in form of conducting researches to develop new products and services, making efforts to provide their students with better services than their competitors through their innovations, and making efforts to improve student loyalty.

Cost leadership (Porter, 1980) requires having powerful cost reductions resulting from experiences as well as strict, high-efficiency controls of overhead and cost. To accomplish low total cost, easier access to the resources and effective cost controls are required. In addition, cost leadership must aim to give service to the large scaled customer groups to make volume and convenience at product design. The biggest competitive advantage of large scaled foundation universities against lately founded universities or especially, state universities against foundation universities is cost leadership.

Focus strategy (Porter, 1980) is to focus on a narrow group of buyers, product, or on a specific geographic region. The strategic objectives at the basis of the focus strategy are oriented towards the group which the strategy is focused on, not for all the sectors of activity, while each function of the business implements its politics with regard to the implementation phase of this strategy. Focus strategies at universities may take the form of condensation in a geographic region, or provide training in niche areas which have not been entered before.

Generating a strategy is an organizational level process which has various stages. The activities in that process include many aspects of analysis, planning, decision making, strategic orientation, and organizational culture, a shared system of values and visions of the organization (Dess, Lumpkin \& Covin, 1997). However, sometimes it is a personal process driven by a powerful CEO which depends on his/her personality.

\subsection{Personality Characteristics of Executives, and Strategy Selection}

Whether or not the executives have different choices and orientations which are originated from their personal characteristics is a serious issue, regardless of environmental or organizational conditions which are related to mechanisms of decision of the organizations. In the literature, a wide variety of researches, which put emphasis on the personality of senior managers or executives in the "strategic decision-making" process which in turn influence the whole process, can be found (Child, 1972; Hambrick \& Mason, 1984; Miller \& Tholouse, 1986).

The effect of managerial background characteristics on strategy selection and performance level was dealt with as a behavioral element in the qualitative studies of Hambrick \& Mason (1984). In this study, strategy selection 
is seen as the reflection of observable features of the manager (age, education, previous experience, socioeconomic background etc.) and psychological features (cognitive values).

In a study conducted by Miller, Manfred, Vries \& Toulouse (1982), there is a direct and important connection between the features of corporate strategies and locus of control of top executives. However, it was found to have an indirect relationship with the environment and the structure. Executives with an internal locus of control seem to have a product-market innovation approach, they take more risks, and they manage their rivals rather than follow them.

Miller \& Toulouse (1986) examined the relationship between three aspects of the chief executive's (CEO's) personality and the strategies, structures, decision making methods, and performance of their firms. Research results showed that there is a relationship among CEO flexibility and niche strategies, simple, informal structures, and intuitive, risk-embracing decision making. There is a relationship between a CEO's need for achievement and marketing-oriented strategies, formal and sophisticated structures, and proactive, analytical decision making, which has been broadly focused on. Executives with an internal locus of control are more into modification, they are more careful about the future, and they can adjust their styles to the situations that their companies may undergo. Small firms and dynamic workplaces are more easily affected by the connection between the CEO's personality and the features of the organization. Flexibility and locus of control are found to be related to corporate performance under certain conditions.

Wally \& Baum (1994) analyzed the strategic decision making pace and personal structural determiners of strategic decision making. As a result of this study, a positive relationship between the pace of decision making and the cognitive abilities of chief executive officers, their use of cognition, tolerance for risk, and propensity to act was found.

However, the research on operating small businesses in Turkey by Doğan \& Özdemirci (2011) found deliberate and external oriented business owners or leaders to perceive crises as threats and, therefore, choose defensive strategies. Also, leaders whose risk propensity is low will choose defensive strategies, too.

Uncertainty avoidance is "the extent to which the members of a culture feel threatened by uncertain or unknown situation" (Hofstede, 1991). In the research of Doğan \& Özdemirci (2011), two dimensions of uncertainty avoidance emerged: deliberate and normative. Whereas deliberate uncertainty avoidance involves characteristics like remaining wary about possible problems before taking action, paying importance to sustaining the current situation, or being rather uncomfortable if there is uncertainty about the responsibilities, normative refers to the characteristics; to believe in clear rules and regulations is very important for the employees, to think of job descriptions and procedures are essential for the business life.

Also, this study examines the uncertainty avoidance characteristics of the rectors, whether they are related to the strategic preferences of the universities. In recent years, the university administration underwent a fundamental revision and almost all of the rectors have been replaced. This situation alerted us to establish our hypotheses more carefully. For example, setting up a hypothesis claiming that personal characteristics and worldviews of university rectors affect the level of corporate entrepreneurship and strategy of a university will be meaningless when one considers that most of the rectors are on the job for only two years. Instead, it is more meaningful to look at the interrelationship between personality traits of the rectors and strategic choices and levels of corporate entrepreneurship of the universities. So if the rectors were managing the universities for many years, just like previous studies assume, the effect could be examined using the regression analysis as one direction. However, our claim will be examined at the level of the reciprocal relationship, which will be measured using correlation analysis - because most of the rectors are at the head of the universities two years or less. Here, the logic of the reciprocal relationship is: to appoint a rector who is adequate the strategy of the university which has a certain strategy, and have the appointed rector direct the strategy in accordance with his/her character. A similar situation is expected to be valid related to the political view of the rector. In this connection, the first hypothesis of our research is obtained as follows:

$H_{1}$ : There is a relationship between strategic choices of the universities and personality traits and worldview of the rectors.

One of the theories, which is frequently used in the studies on the relationship between individual entrepreneurship and personality traits, is McClelland's need theory (1961). Another one is Rotter's theory of locus of control (1966).

According to McClelland's (1961) theory, individuals who sense the most need for achievement want to solve their own problems, set targets, and achieve their goals through their own efforts. This theory argues that 
individuals who have strong need for achievement often enter the path of entrepreneurship, and that they are more successful as an entrepreneur.

According to Rotter (1966), locus of control of an individual may range from internal to external. The internal controls expectancy means that one establishes control over one's own life. Here the results of one's actions depend on one's own behavior or character traits. The external controls expectancy indicates behavior types which focus on other people's activities, fate, luck or opportunities. According to Rotter's theory (1966), internal control expectancy supports active work and provides motivation in this direction because there is a relationship between internal control expectancy and learning. External control expectancy not only obstructs learning, but also encourages remaining passive. Internal control expectancy is usually associated with the features of entrepreneurship.

The effects of the personality on changes in the relationships of entrepreneurs were measured in the study by Hittunen (2000). The achievement motivation of entrepreneur personality traits was measured in four dimensions: work ethic, pursuit of excellence, mastery, and dominance. Locus of control was discussed in 3 dimensions: internal attributing, chance attributing, and powerful others. According to the results of the researches, being an entrepreneur and working as an entrepreneur are processes of learning. This also creates an effect on the entrepreneur's personality traits. The motivation of the entrepreneur to solve problems is increasing and control of the other powerful people in the organization is decreasing. In addition, the change in the entrepreneur's relationships with other people was observed to have an effect on the entrepreneur's personality traits.

As we have seen, there are lots of researches which review the relationship between individual entrepreneurship and personality traits. However, the literature on corporate entrepreneurship does not seem to focus notably on personality traits or political opinions. But a manager's personality traits have a significant effect on the behavior of the business, its policies and climate, even in the largest businesses. The issue of corporate entrepreneurship is directly related to the innovative climate to be created in the organization. Also here, our hypothesis will be based on a reciprocal relationship because a rectors' time in the management is limited:

$\mathrm{H}_{2}$ : There is a relationship between the personality traits of the rectors and the levels of corporate entrepreneurship of universities.

Corporate entrepreneurship has been recognized as an important tool for improving the position of institutions and supporting a competitive advantage (Covin \& Miles, 1999). For example, Miller (1983), Khandwlla (1987), Guth \& Ginsberg (1990), Naman \& Slevin (1993), and Lumpkin \& Dess (1996) specified that corporate entrepreneurship can be used to change institutions, markets, industries, and the competitive position as long as value creation opportunities are raised and used.

Covin \& Miles (1999) have demonstrated a theoretical relationship between a competitive advantage and the dimensions of corporate entrepreneurship in a qualitative study. The dimensions of corporate entrepreneurship in the study are categorized as sustained regeneration, organizational rejuvenation, strategic renewal, and domain redefinition. In this study, two basic strategies (cost leadership and differentiation), which are suggested by Porter (1980), are being used to provide a competitive advantage. Furthermore, the organizational rejuvenation dimension of corporate entrepreneurship and cost leadership strategy are associated with each other. Accordingly, it is possible that organizational rejuvenation may create advantages depending on cost reducing activities of the organization by focusing internally and externally. And also, a differentiation strategy and sustained regeneration of corporate entrepreneurship are associated. Accordingly, as it was seen that the realized competitive advantage depending on diversity may be used widely by companies that are interested in a sustained regeneration form of corporate entrepreneurship. Finally, quick response and domain redefinition dimension of corporate entrepreneurship are associated. Accordingly, redefining the area drags the competition to a new product area. If opponents have not entered this area yet, it can be said that they use quick response for competitive advantage.

In a research by Barringer \& Bluedorn (1999), the relationship between the intensity of corporate entrepreneurship and five specific strategic management applications were examined in 169 production companies from USA. The five strategic management applications are: scanning intensity, planning flexibility, planning horizon, locus of planning, and control attributes. The results of the study show that there is a positive correlation between scanning intensity, planning flexibility, planning focus, strategic controls, and corporate entrepreneurship intensity. 
Also in this study, a meaningful relationship between the strategic orientation of universities and the dimensions of corporate entrepreneurship (particularly of differentiation strategies) is expected. In this connection, the third hypothesis of the study is generated as follows:

\section{$H_{3}$ : There is a relationship between levels of corporate entrepreneurship of universities and strategy selection.}

\section{Research Methodology and Results}

\subsection{Data Collection and Instrument}

The type of research applied is hypothetic research. A survey consisting of 55 questions was prepared, and we tried to contact the rectors of all 105 public and 64 private universities operating in Turkey and convince them to participate in the survey. The results of the surveys were obtained through face-to-face interviews or e-mail.

\subsection{Measures}

The survey prepared for the research has 55 questions. As seen in Table 1, the measure of Corporate Entrepreneurship has 16 items (Antoncic \& Hisrich, 2003; Özdemirci, 2011), the measure of Competitive Strategy has 16 items (Porter, 1980; Wan, 2004), the measure of Uncertainty Avoidance has 5 items (Voich, 1995), and the measure prepared for this article, which is about the political views of the rectors, has 10 questions. There are also 8 questions about the demographics. The Likert Scale-5 is used in all questions.

Table 1. Measures used in research

\begin{tabular}{|c|c|c|}
\hline Measure & Developers & Item Number \\
\hline Corporate Entrepreneurship & $\begin{array}{l}\text { Antoncic and Hisrich (2003); } \\
\text { Özdemirci (2011) }\end{array}$ & 16 \\
\hline Competitive Strategy & Porter (1980), Wan (2004) & 16 \\
\hline Uncertainty Avoidance & Voich (1995) & 5 \\
\hline $\begin{array}{l}\text { Rector's Political View } \\
\text { (Conservator - Libertarian) }\end{array}$ & Original Scale & 10 \\
\hline
\end{tabular}

The questions about the corporate entrepreneurship and competitive strategy scales were not changed but only adapted to the universities. In the preparation process of the questions, which aimed at measuring the political views of the rectors, the validity analyses were made. Validity is a concept related to whether a research is suitable for its purposes, and whether a data collection technique used in a research is adequate or not. In other words, the validity is the trust to a differentiation resulting from measurements in a research completely originating from the measured phenomenon or people. Although there are many different classifications related to validity, we can speak about three types of validities which basically are: Content validity, criterion-related validity and construct validity. The sub-dimensions of these validities are (i) face validity, (ii) concurrent validity and predictive validity, (iii) convergent validity and discriminant validity (Saruhan \& Özdemirci, 2011).

Content validity is related to how much the scale represents of the searched concept. The more the questions a scale represent the measured concept, the higher the scope validity of the scale will be. In order to test the validity of the scope of this study, firstly, the literature was read and then a six-person focus group composed of academics was consulted. Also, the political orientation of the university administration and the news, which appeared in the press, were examined, and these mentioned subjects were included in the scale. Criterion-related validity is related to whether the scale could afford to put out the differentiations between people as expected or not. Also, the results were different as they were obtained by unalike individuals. Prior to the survey, we observed that differences in rectors' views were reflected within the results of the survey, which were put forward by the majority of the university rectors during TV interviews conducted by Görkem Ildaş, who made a TV program on University Management at Show TV, and one of the authors of this article. Finally, construct validity is related to whether the results obtained from scale correspond to the related theories. We will come back to this issue during the examination of the results of the correlation analysis. As a result of this analysis, the questions used in the "Rector's Political View" scale are shown in Table 2. 
Table 2. Rector's political view scale

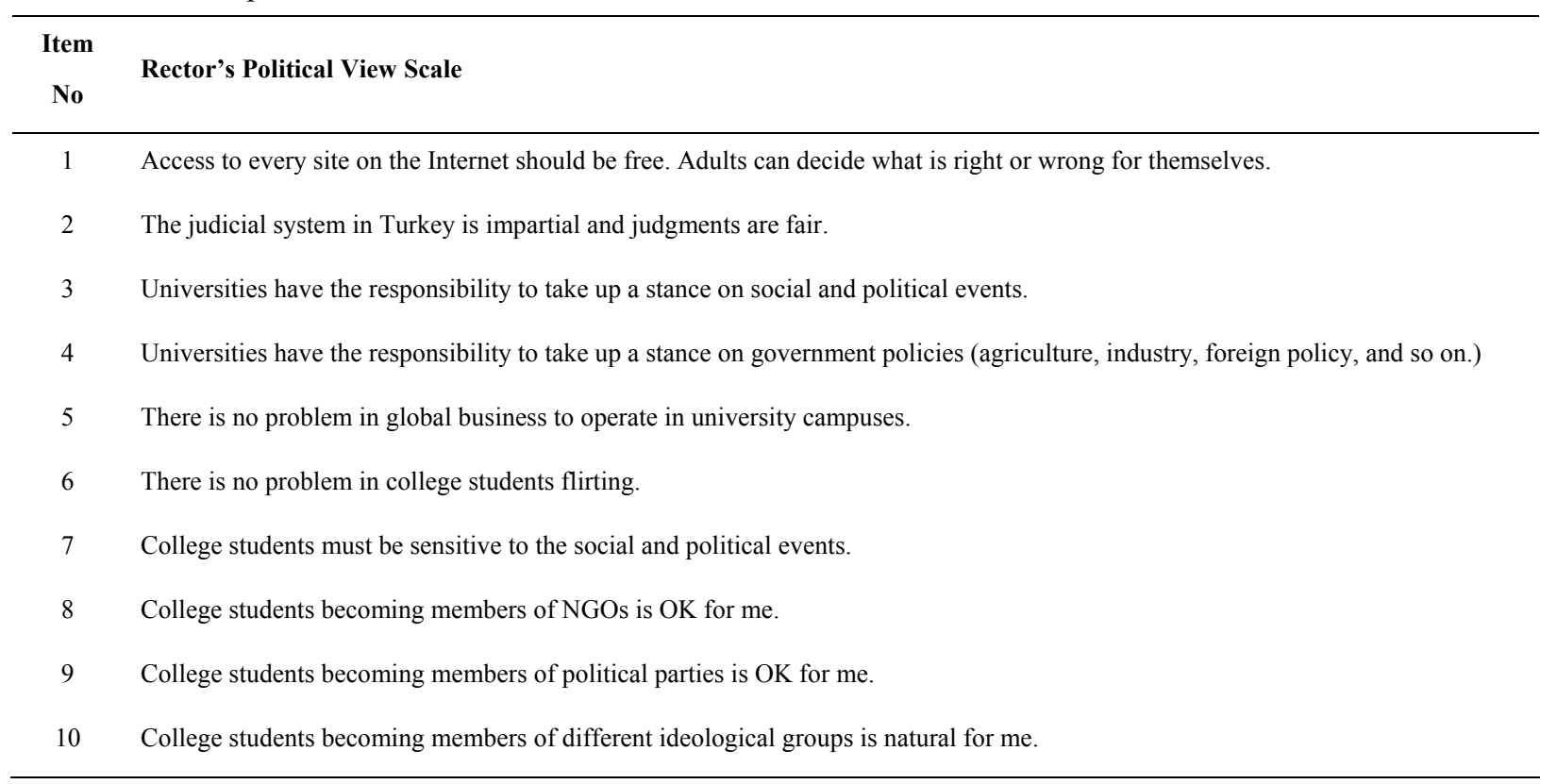

While these questions were being prepared, we focused on liberalism or conservatism levels of the rectors on the agenda issues related to universities, rather than trying to obtain all dimensions of multi-layered concepts such as political opinions. This eliminates the problem of the scope of the subject, and the opinions of the rectors on the most discussed current issues were obtained clearly. Indeed, the answers to these questions of the rectors have become news on the internet media portals and in lots of newspapers through the newsletter we prepared.

\subsection{Factor Analysis and Reliabilities}

Factor analysis is used to determine the dimensions of the measures. Also Cronbach's Alpha Test for reliability, Pearson and Partial Correlation, and t-tests are made via SPSS 17.0 to measure the power of hypothesis.

Expletory factor analysis is made for establishing the sub dimensions of measures. All factors have passed the KMO Measure of Sampling Adequacy and Bartlett test of Sphericity which means that our data set is appropriate for factor analyses. Principal components and varimax method are used in analysis. For all measures, items which have a factor weight below 0,50 ; unique items in a factor; items with close factor weights are left out of evaluation. After this processes, factors which have initial eigenvalues over 1,00 and Cronbach Alpha over 0,50 are:

4 factors in Corporate Entrepreneurship Measure (Cumulative Extraction Sums $=\% 75,325)$ which can be called Innovativeness (Cronbach Alpha $=0,875$ ), New Business Venturing (Cronbach Alpha $=0,829$ ), Rewarding Innovation (Cronbach Alpha $=0,965)$ and Risk Taking (Cronbach Alpha $=0,553)$.

3 factors in Competitive Strategy Measure (Cumulative Extraction Sums $=$ \%72,021) which can be called Differentiation (Cronbach Alpha $=0,874$ ), Focus (Cronbach Alpha $=0,724$ ) and Cost Leadership (Cronbach Alpha $=0,726$ ).

2 factors in Uncertainty Avoidance Measure (Cumulative Extraction Sums=\%65,544 which can be called Deliberate (Cronbach Alpha $=0,518$ ) and Normative (Cronbach Alpha $=0,677)$.

3 factors in Rector's Political View Measure (Cumulative Extraction Sums $=\% 81,385$ which can be called Libertarianism and Participatory Democracy Faith (Cronbach's alpha $=0.773$ ), Believing University has Political Responsibility (Cronbach's alpha $=0.844$ ) and Believing Students are Required to be Politically Active $($ Cronbach's alpha $=0.766)($ Table 3$)$. 
Table 3. The results of factor and reliability analysis

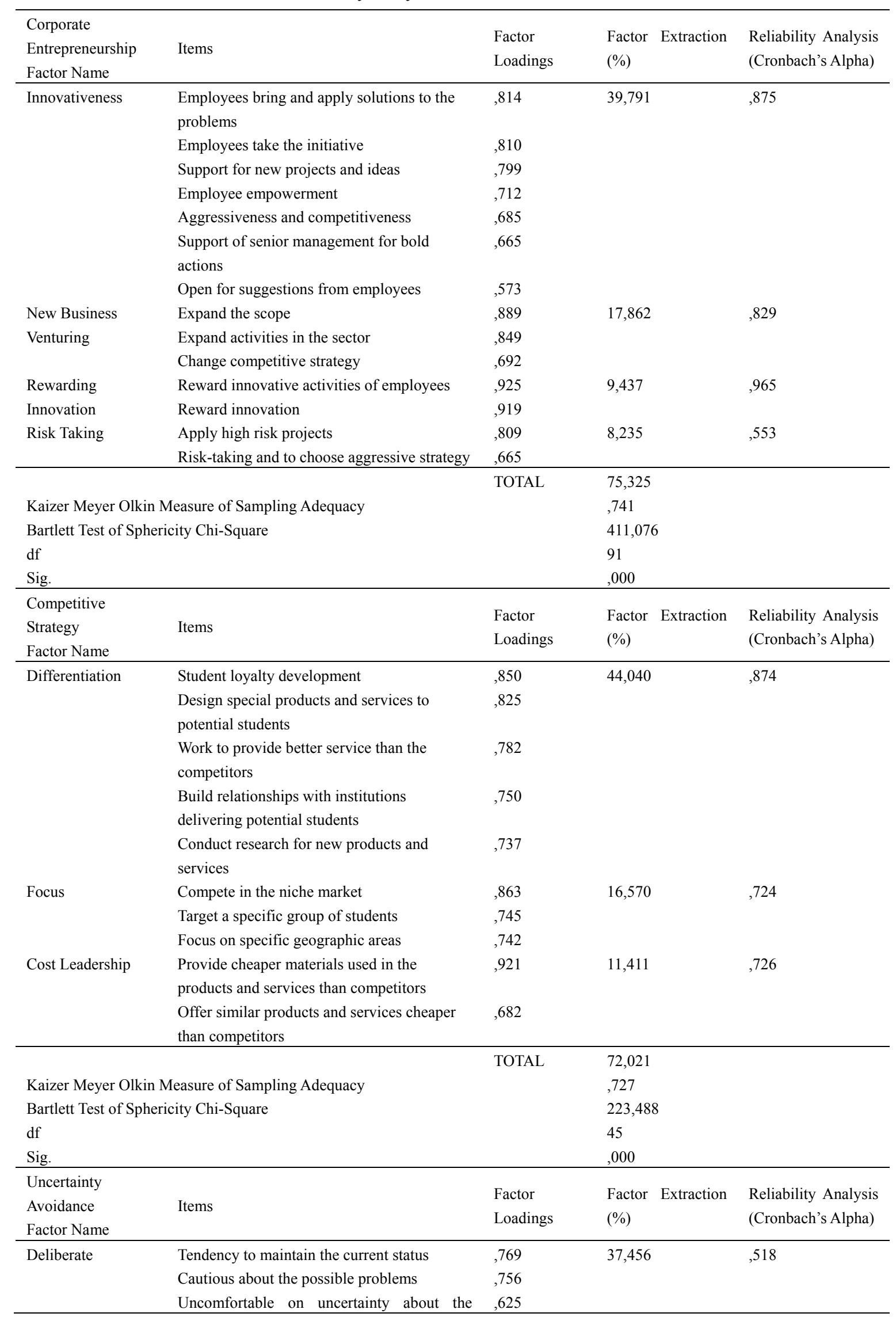




\begin{tabular}{|c|c|c|c|c|}
\hline \multirow{3}{*}{ Normative } & \multicolumn{4}{|l|}{ responsibilities } \\
\hline & The importance of clear rules and regulations & ,886 & 28,088 & 677 \\
\hline & Job descriptions and procedures are vital & ,823 & & \\
\hline & \multirow{3}{*}{\multicolumn{2}{|c|}{$\begin{array}{r}\text { TOTAL } \\
\text { Kaizer Meyer Olkin Measure of Sampling Adequacy } \\
\text { Bartlett Test of Sphericity Chi-Square }\end{array}$}} & 65,544 & \\
\hline & & &, 549 & \\
\hline & & & 42,724 & \\
\hline & & df & 10 & \\
\hline & \multicolumn{2}{|r|}{ Sig. } &, 000 & \\
\hline Rector's Political & \multirow{3}{*}{ Items } & & & \\
\hline $\begin{array}{l}\text { View (Conservator } \\
\text { - Libertarian) }\end{array}$ & & $\begin{array}{l}\text { Factor } \\
\text { Loadings }\end{array}$ & $\begin{array}{l}\text { Factor Extraction } \\
(\%)\end{array}$ & $\begin{array}{l}\text { Reliability Analysis } \\
\text { (Cronbach's Alpha) }\end{array}$ \\
\hline \multicolumn{4}{|l|}{ Factor Name } & \\
\hline $\begin{array}{l}\text { Faith in Liberalism } \\
\text { and Participatory }\end{array}$ & $\begin{array}{l}\text { Support students' awareness of social and } \\
\text { political events }\end{array}$ & ,912 & 42,633 &, 773 \\
\hline \multirow[t]{2}{*}{ Democracy } & Consider students to flirt normal & ,788 & & \\
\hline & $\begin{array}{l}\text { Consider students to be member of an NGO } \\
\text { normal }\end{array}$ & ,749 & & \\
\hline $\begin{array}{l}\text { Believing } \\
\text { University has }\end{array}$ & $\begin{array}{l}\text { Universities must take a stance on } \\
\text { government policies }\end{array}$ & ,929 & 24,597 & 844 \\
\hline $\begin{array}{l}\text { Political } \\
\text { Responsibility }\end{array}$ & $\begin{array}{l}\text { Universities must take a stance on social } \\
\text { events }\end{array}$ & ,888 & & \\
\hline $\begin{array}{l}\text { Believing Students } \\
\text { are Required to be }\end{array}$ & $\begin{array}{l}\text { Consider students to be members of a } \\
\text { political party normal }\end{array}$ & ,930 & 14,155 & ,766 \\
\hline \multirow[t]{2}{*}{ Politically Active } & $\begin{array}{l}\text { Consider students to be member of } \\
\text { ideological groups normal }\end{array}$ &, 890 & & \\
\hline & & TOTAL & 81,385 & \\
\hline \multicolumn{3}{|c|}{ Kaizer Meyer Olkin Measure of Sampling Adequacy } & ,604 & \\
\hline \multicolumn{3}{|c|}{ Bartlett Test of Sphericity Chi-Square } & 151,069 & \\
\hline \multicolumn{3}{|c|}{ df } & 21 & \\
\hline \multicolumn{3}{|l|}{ Sig. } &, 000 & \\
\hline
\end{tabular}

\subsection{Descriptive Statistics and Correlations}

64 rectors of 169 universities participated in the survey (37.8\% return rate), not fully filled 7 questionnaires were excluded. $32(56,1 \%)$ surveys are from public and $25(43,9 \%)$ surveys are from foundation university. The Likert-5 Scale was used in the research. The rectors' average service period in the universities is 16,2 years $37.2 \%$ of the rectors' service period is 5 years or below, most of which work at newly founded universities.

What continues to be one of the most controversial issues over the years is "the university's language of instruction". $73,7 \%$ of the rectors stated that "part of the required courses must be in Turkish, part of the required courses must be in a foreign language", $15,8 \%$ stated that education must be "completely Turkish", $10,5 \%$ stated as "completely foreign-language".

While the law of the administrative structure of the public universities is on the verge, $59,6 \%$ of the rectors stated "completely autonomous", 31,6\% stated "semi-autonomous", 3,5\% stated "universities must be based on the government" related with the subject. Also 45,6\% stated "foundation status", 36,8\% stated "private status", $5,3 \%$ stated "some private and some foundation status" related with the administrative structure of the universities which do not depend on the public.

Rectors expressed they spend an average of 6,1 hours of the week on "communicating face to face with students" (min: 0; max: 24 hours) and 4,1 hours of the week by "communicating via social media" (min: 0; max: 12 hours).

The rectors' term of office is 1,9 years in average. $70,2 \%$ of the rectors had been assigned for less than 2 years. The longest term of office is 5 years.

\subsubsection{Political Views of Rectors}

Only $52,6 \%$ of the rectors agreed (agree and strongly agree) with the expression "Access to every website should be free on the internet. Adults can decide what is right or wrong for themselves" and only $42,1 \%$ agreed 
with the expression "There is no harm in university students flirting". This doesn't look like a libertarian view. But when it comes to the global capital case, most rectors $(66,7 \%)$ look like libertarians and agree with the expression "There is no harm in global enterprises performing business activities inside university campuses", which proves the political dilemma we mentioned before.

$70,2 \%$ of the rectors agreed with the expression "Universities have the responsibility to display their stance regarding social and political incidents", 72,4\% agreed with the expression "Universities have the responsibility to display their stance regarding government policies (agriculture, industry, foreign policies etc.)", and 78,9\% agreed with the expression "University students should be sensitive to social and political incidents". We see that most of the rectors feel responsible to the main issues in a country.

While $84,2 \%$ agreed with the expression "I lean towards NGO memberships of university students", only $54,4 \%$ agreed the expression "I find university students' memberships in various ideological student groups natural", and $47,4 \%$ supported "I lean towards political party memberships of university students". This is a very important sign of the negative image of political parties and ideological groups in Turkey.

Despite their political cohesion with the current government, only $35,1 \%$ of the rectors agreed with the expression "The legal system in Turkey is neutral and trials are fair". This indicates a very big problem of justice in Turkey.

The expression rectors agree on most was "Universities have the responsibility to display their stance regarding government policies (agriculture, industry, foreign policies etc.)" (Mean=4,34), and the expression they agreed on the least was "The legal system in Turkey is neutral and trials are fair." (Mean=2,84).

The expression which has the highest standard deviation, that is, the expression in which replies differentiate the most, was "I find university students' memberships in various ideological student groups natural" (Standard Deviation=1,51), whereas the expression to which rectors gave similar replies was "University students should be sensitive to social and political incidents" (Standard Deviation=0,89).

\subsubsection{Risk-Taking-Uncertainty Avoidance Tendencies of Rectors}

Rectors "Show respect to people taking risks" (Mean=4,20), they believe "Risk-taking and going for an adventure is an important experience for the existence of man" (Mean=4,00); however, it is observed that rectors have a pretty high tendency of avoiding uncertainty, especially in their business lives. They believe "Clear rules and regulations are important for the employees" (Mean=4,57), they think "Job descriptions and procedures are prerequisites for business life" $(\mathrm{Mean}=4,28)$, and they say that they show "Deliberate behavior regarding possible problems before taking action" (Mean=4,02).

\subsubsection{Corporate Entrepreneurship}

The expression rectors agreed on most among corporate entrepreneurship was "University management supports new projects and opinions" (Mean=4,68). The expression they agreed on least was "Our university is implementing the strategy of obliterating competitors by unraveling them" (Mean=2,07).

\subsubsection{Competitive Strategy}

The expressions on the subject of competitive strategy used which rectors agreed on most were "Putting through studies to present better service to its students than the competitors" (Mean=4,34), "Carrying through researches to develop new products and services" (Mean=4,17) and "Investing to make processes more efficient" $(\mathrm{Mean}=3,95)$. The expressions they least agreed on were "Focusing on certain geographical regions" (Mean=3,13), "Targeting a specific group of students" (Mean=2,63) and "Competing in niche (specific to a small target group) fields" (Mean=2,30). 
Table 4. Pearson correlation test

\begin{tabular}{|c|c|c|c|c|c|c|c|c|c|c|c|c|c|c|}
\hline & Mean & S.D. & 1 & 2 & 3 & 4 & 5 & 6 & 7 & 8 & 9 & 10 & 11 & 12 \\
\hline 1. Innovativeness & 4,16 & ,64 & 1 & & & & & & & & & & & \\
\hline 2. New Business Venturing & 3,79 & 1,03 & ,253 & 1 & & & & & & & & & & \\
\hline 3. Rewarding Innovation & 4,11 &, 87 &, 180 &, $431^{* *}$ & 1 & & & & & & & & & \\
\hline 4. Risk Taking & 3,49 & 1,01 &, $452^{* *}$ &, $331^{*}$ &, $420^{* *}$ & 1 & & & & & & & & \\
\hline 5. Differentiation & 4,03 &, 75 &, $450^{* *}$ &, 189 &, 095 &, $313^{*}$ & 1 & & & & & & & \\
\hline 6. Focus & 2,71 & 1,01 &,- 154 & 247 &, $287^{*}$ & ,227 &, $332^{*}$ & 1 & & & & & & \\
\hline 7. Cost Leadership & 3,79 & ,92 & ,206 & 053 & 003 &, 189 &, $531^{* *}$ &, 160 & 1 & & & & & \\
\hline $\begin{array}{l}\text { 8. Faith in Liberalism and } \\
\text { Participatory Democracy }\end{array}$ & 3,96 &, 89 &, 069 &, 157 &,- 165 &,- 008 &, $423^{* *}$ &, 188 &, 000 & 1 & & & & \\
\hline $\begin{array}{l}\text { 9. Believing University has } \\
\text { Political Responsibility }\end{array}$ & 4,15 & ,93 &, 121 & 026 &,- 104 & ,203 & 246 &,- 094 &, 170 &, $432^{* *}$ & 1 & & & \\
\hline 10. Believing Students are & & & & & & & & & & & & & & \\
\hline Required to be Politically & 3,34 & 1,31 &,- 005 &, 195 &,- 017 & 194 &,- 087 &, 133 &,- 081 &, $276^{*}$ & 017 & 1 & & \\
\hline Active & & & & & & & & & & & & & & \\
\hline 11. Deliberate & 3,36 &, 82 &,- 041 & ,206 &,- 012 &,- 043 & $305^{*}$ &, $294^{*}$ & ,233 & ,123 & ,116 &,- 222 & 1 & \\
\hline 12. Normative & 4,43 & 68 &,- 116 &,- 172 &,- 039 & 058 &, $316^{*}$ & ,275 & , 180 & ,104 & 229 &,$- 375^{* *}$ &, 135 & 1 \\
\hline
\end{tabular}

Sample Size $=57 ;{ }^{*} \mathrm{p}<0,05, * * \mathrm{p}<0,01$.

When we look at factor means, we observe that universities give importance to innovativeness and rewarding innovation within the scope of corporate entrepreneurship of universities. New business venturing and risk-taking, which we thought we would not see much of in state universities, especially due to the structure of the sector, were implemented in significant rates both in state and in foundation universities.

We observe that the differentiation strategy is in the lead by a long shot, and universities do not gravitate to focus a lot, when we glance to the strategies of the universities. Cost leadership also occupies a significant place both in state and foundation universities due to saving measures. Time will tell whether this is a strategy in the real sense or just a sectoral tendency. However, if we had to make a general analysis: the growth rate of education encourages universities to do research to develop new products and services, to improve student loyalty, and at the same time provides the opportunity to ensure and offer similar products and services with more affordable prices than their competitors.

When we observe political views of rectors, we see they are mostly on the side of liberalism. The result that rectors generally prefer liberalism-even if these are their own declarations-is significant for us considering that the public opinion on rectors is negatively prejudiced due to the method of their appointment. Even though Turkish media portrays the subject in a negative light, it can be easily said that the few rectors who stated they are strongly against flirting or internet freedom do not represent the majority. But the support of freedom is still not enough.

When we look at rectors' personality traits, we see that they have extremely normative natures and they are significantly deliberate. It is not astounding to observe these features extensively in people on the higher echelons of bureaucratic organizations.

When we look at the results of correlation analysis, it is observed that rectors in universities applying differentiation strategies are more liberal. According to this, it can be put forth that the innovative and free-thinking environment necessary for the existence of a differentiation strategy is more preferable for university rectors who have this liberal mentality. This conclusion is compatible with the literature as well. On the other hand, in the conclusion of the survey, it was observed that rectors of the universities which apply differentiation and focus strategy were more deliberate and normative. Besides, a suspicious outcome is that deliberate rectors focus on new business venturing as well. Here, it should be examined whether the legal structure of a university-that is, differences between foundation universities and state universities, which we think will effect conclusions significantly, although it is not among main hypothesis of the survey-will create a hidden alteration in the survey conclusions or not.

T-test was applied to examine if corporate entrepreneurship, strategic choices, political views and personality traits of rectors of foundation and state universities differed or not. 
Table 5. Comparison of state universities with foundation universities

\begin{tabular}{|c|c|c|c|c|c|}
\hline & $\begin{array}{l}\text { Administrative } \\
\text { Structure }\end{array}$ & $\mathrm{N}$ & Mean & St. Deviation & $\mathrm{p}$ \\
\hline \multirow[t]{2}{*}{ 1. Innovativeness } & State & 30 & 4,24 & 0,50 & 0,34 \\
\hline & Foundation & 21 & 4,06 & 0,80 & \\
\hline \multirow[t]{2}{*}{ 2. New Business Venturing } & State & 29 & 3,59 & 1,19 & 0,10 \\
\hline & Foundation & 22 & 4,07 & 0,73 & \\
\hline \multirow[t]{2}{*}{ 3. Rewarding Innovation } & State & 31 & 4,08 & 0,95 & 0,80 \\
\hline & Foundation & 25 & 4,14 & 0,78 & \\
\hline \multirow[t]{2}{*}{ 4. Proactivity } & State & 29 & 3,31 & 0,99 & 0,15 \\
\hline & Foundation & 23 & 3,72 & 1,02 & \\
\hline \multirow[t]{2}{*}{ 5. Differentiation } & State & 29 & 3,88 & 0,81 & 0,08 \\
\hline & Foundation & 22 & 4,25 & 0,62 & \\
\hline \multirow[t]{2}{*}{ 6. Focus } & State & 25 & 2,31 & 0,73 & 0,00 \\
\hline & Foundation & 25 & 3,11 & 1,10 & \\
\hline \multirow[t]{2}{*}{ 7. Cost Leadership } & State & 29 & 3,71 & 0,89 & 0,46 \\
\hline & Foundation & 24 & 3,90 & 0,96 & \\
\hline \multirow{3}{*}{$\begin{array}{l}\text { 13. Faith in Liberalism and Participatory } \\
\text { Democracy }\end{array}$} & State & 28 & 3,69 & 0,96 & 0,01 \\
\hline & & & & & \\
\hline & Foundation & 23 & 4,29 & 0,67 & \\
\hline \multirow{3}{*}{$\begin{array}{l}\text { 14. Believing University has Political } \\
\text { Responsibility }\end{array}$} & State & 32 & 4,09 & 1,04 & 0,39 \\
\hline & & & & & \\
\hline & Foundation & 24 & 4,31 & 0,76 & \\
\hline \multirow{3}{*}{$\begin{array}{l}\text { 15. Believing Students are Required to be } \\
\text { Politically Active }\end{array}$} & State & 31 & 3,31 & 1,42 & 0,84 \\
\hline & & & & & \\
\hline & Foundation & 25 & 3,38 & 1,18 & \\
\hline \multirow[t]{2}{*}{ 17. Deliberate } & State & 30 & 3,27 & 0,77 & 0,33 \\
\hline & Foundation & 24 & 3,49 & 0,87 & \\
\hline \multirow[t]{2}{*}{ 18. Normative } & State & 30 & 4,30 & 0,77 & 0,13 \\
\hline & Foundation & 24 & 4,58 & 0,50 & \\
\hline
\end{tabular}

First of all, it draws attention that, even though it is not statistically significant, rectors of foundation universities are more deliberate, normative and do not like to take risks, with foundation universities being more proactive draws attention. Commercial responsibilities and rigorous competition conditions, which foundation universities are against, explain the reason why these universities work with more deliberate, normative rectors not liking to take risks.

It is also observed that foundation universities use focus strategy significantly more $(p<0,05)$, and that rectors of foundation universities have significantly more faith in liberalism and participatory democracy than the rectors of state universities, as well. Besides these, new business venturing levels and differentiation strategy utilization rates of foundation universities are higher than state universities $(\mathrm{p}<0,10)$.

So, it should not be ignored in the conclusion regarding university rectors using differentiation strategies being more liberal and more deliberate-normative, that these rectors generally work in foundation universities. A correlation between differentiation strategies and deliberate-normative rectors is probably arising from the fact these rectors are working in foundation universities. For this reason, a new correlation analysis was performed where administrative structure of the university was treated as control variable and partial correlation test was used for this analysis. 
Table 6. Partial correlation test

\begin{tabular}{|c|c|c|c|c|c|c|c|c|c|c|c|c|c|c|}
\hline & Mean & S.D. & 1 & 2 & 3 & 4 & 5 & 6 & 7 & 8 & 9 & 10 & 11 & 12 \\
\hline 1. Innovativeness & 4,16 & 0,64 & 1 & & & & & & & & & & & \\
\hline 2. New Business Venturing & 3,79 & 1,03 & 0,298 & 1 & & & & & & & & & & \\
\hline 3. Rewarding Innovation & 4,11 & 0,87 & 0,156 & ,404* & 1 & & & & & & & & & \\
\hline 4. Risk Taking & 3,49 & 1,01 &, $480 * *$ & 0,233 &, $362^{*}$ & 1 & & & & & & & & \\
\hline 5. Differentiation & 4,03 & 0,75 &, $539^{* *}$ & 0,145 & $-0,021$ & 0,306 & 1 & & & & & & & \\
\hline 6. Focus & 2,71 & 1,01 & $-0,133$ & 0,164 & 0,271 & 0,144 & 0,117 & 1 & & & & & & \\
\hline 7. Cost Leadership & 3,79 & 0,92 & 0,124 & 0,118 & $-0,127$ & 0,164 &, $544 * *$ & 0,186 & 1 & & & & & \\
\hline $\begin{array}{l}\text { 8. Faith in Liberalism and } \\
\text { Participatory Democracy }\end{array}$ & 3,96 & 0,89 & 0,129 & 0,072 & $-0,201$ & $-0,14$ &, $533 * *$ & 0,028 & 0,195 & 1 & & & & \\
\hline $\begin{array}{l}\text { 9. Believing University has } \\
\text { Political Responsibility }\end{array}$ & 4,15 & 0,93 & 0,084 & $-0,089$ & $-0,172$ & 0,208 & 0,266 & $-0,222$ & 0,354 & 0,29 & 1 & & & \\
\hline 10. Believing Students are & & & & & & & & & & & & & & \\
\hline Required to be Politically & 3,34 & 1,31 & 0,032 & 0,229 & $-0,069$ & 0,169 & 0,145 & 0,335 & 0,13 & 0,263 & $-0,121$ & 1 & & \\
\hline Active & & & & & & & & & & & & & & \\
\hline 11. Deliberate & 3,36 & 0,82 & $-0,006$ & 0,079 & $-0,159$ & $-0,068$ & 0,245 & 0,174 & 0,314 & 0,146 & 0,15 & $-0,089$ & 1 & \\
\hline 12. Normative & 4,43 & 0,68 & $-0,227$ &,$- 392 *$ & $-0,282$ & $-0,067$ & 0,03 & 0,047 & 0,093 & $-0,003$ & 0,21 &,$- 398^{*}$ & 0,042 & 1 \\
\hline
\end{tabular}

Sample Size $=57 ;{ }^{*} \mathrm{p}<0,05,{ }^{* *} \mathrm{p}<0,01$; Control Variable: Administrative Structure of Universities.

According to the conclusions of the analysis:

For Hypothesis 1 (There is a correlation between strategic choices of universities and world views and personality traits of rectors):

- Rectors in universities applying differentiation strategies are more liberal and their faith in participatory democracy is stronger. This is the sole significant relation among relations between strategy and world view.

For Hypothesis 2 (There is a correlation between corporate entrepreneurship levels of universities and personality traits of rectors):

- New business venturing levels are affected in the most negative way in the universities where rectors with normative personality traits work. This is the sole significant relation among relations between corporate entrepreneurship and personality traits of the rector. Even though not taking place among our hypotheses, it is worthy of attention that rectors with more normative personality traits have less faith in students being required to be in active politics.

For Hypothesis 3 (There is a correlation between corporate entrepreneurship level of universities and their choice of strategy):

- It is observed that the innovativeness dimension of corporate entrepreneurship is in extreme harmony with differentiation strategies. This is the sole significant relation among relations between corporate entrepreneurship and strategic choice.

\section{Conclusion}

The aim of this research was (1) to put forth corporate entrepreneurship levels and strategic tendencies of state and foundation universities having activities in Turkey, and (2) to question if there is any correlation between these tendencies and political views and personality traits of the rectors or not.

The first clear finding of the research is that rectors are more liberal in universities implementing differentiation strategies. According to this, it can be stated that the innovative and free-thinking environment necessary for the existence of differentiation strategies is more preferable for university rectors who have this liberal mentality. This conclusion is compatible with the literature as well, but new for university management.

The second clear finding of the research is that normative rectors are distant to new business venturing. Normativeness basically represents loyalty to official job descriptions and a tendency to rules and regulations. For this reason, it is more reasonable that normative administrators do not lean towards risk-taking and new business venturing, which would raise uncertainty. This puts forth that, independent of market conditions, 
personality traits of top managers will affect corporate entrepreneurship level of the institution.

The third clear finding of the research is that innovativeness is compatible with differentiation strategies, as has been revealed many times in the literature. The basis of the differentiation strategy is a production of goods and services which will be accepted as unique in the indicated sector. Naturally, the path for this goes through innovativeness. Differentiation strategies in a university are applied in the form of research to develop new products and services, trying to offer a better service than competitors with its innovations and working to improve student loyalty.

When we glance at additional findings of the research, it attracts attention that rectors who have normative personality traits have little belief that students should be active politically; and rectors of foundation universities are more deliberate, normative and do not like to take risks. Even though personality traits of foundation university rectors are deliberate and normative, their faith in liberalism and participatory democracy is significantly higher than rectors of state universities.

Commercial responsibilities of foundation universities and the rigors of competition conditions they are against explain the reason why these universities work with rectors who are deliberate, normative and do not like to take risks. That is, foundation universities prefer administrators who are liberal in their world view, more deliberate and normative in their business lives.

Besides, it can be observed that foundation universities use differentiation and focus strategy significantly more than state universities and their levels of new business venturing are higher than those of state universities. Competition is the basic fact triggering corporate entrepreneurship, and this situation reveals itself in the university circuit, as well.

This survey was performed on state and foundation universities being active in Turkey. All comments made in this direction are valid within the scale of Turkey. A comparative survey can be performed in the subsequent surveys assessing university administrations in different countries. Besides, in countries where there are rectors managing universities for many years and there is proper sample, a correlation between an administrator personality and strategic choice-corporate entrepreneurship, can be examined by cause and effect analysis (such as regression analysis or SEM), in which the personality of the rector is the independent variable. Lastly, the effect of corporate culture can be tested as a control variable.

\section{References}

Aktan, C. C. (2007). Yüksek öğretimde değişim: Global trendler ve yeni paradigmalar. In C. Can Aktan (Eds.), Değişim Çă̆ında Yüksek Öğretim. İzmir: Yaşar Üniversitesi Yayını.

Antoncic, B., \& Hisrich, R. D. (2001). Intrapreneurship: Construct refinement, cross-cultural validation. Journal of Business Venturing, 16(5), 495-527. http://dx.doi.org/10.1016/S0883-9026(99)00054-3

Antoncic, B., \& Hisrich, R. D. (2003). Clarifying the intrapreneurship concept. Journal of Small Business, Enterprise Development, 10(1), 7-24. http://dx.doi.org/10.1108/14626000310461187

Antoncic, B., \& Hisrich, R. D. (2004). Corporate entrepreneurship contingencies, organizational wealth creation. Journal of Management Development, 23(6), 518-550. http://dx.doi.org/10.1108/02621710410541114

Baden-Fuller, C., \& Stopford, M. J. (1994). Rejuvenating the mature business. Boston, MA: Harvard Business School Press.

Barringer, B., \& Bluedorn, A. C. (1999). The relationship corporate entrepreneurship and strategic management. Strategic Management Journal, 20, 421-444.

Burgelman, R. A. (1984). Designs for corporate entrepreneurship. California Management Review, 26, $154-166$.

Cameron, K. (1983). Strategic responses to conditions of decline: Higher Education and the Private Sector. Journal of Higher Education, 54(4), 359-380.

Chaffee, E. E. (1985). The concept of strategy: From business to higher education. In J. Smart (Eds.), Higher Education: Handbook of Theory and Research (Vol. 1). New York: Agathon.

Chaffee, E. E. (1989). Strategy and effectiveness in systems of higher education. In J. Smart (Eds.), Higher Education: Handbook of Theory and Research (Vol. 5). New York.

Clark, B. R. (1998). Creating Entrepreneurial Universities Organizational Pathways of Transformation. New York: IAU Press. 
Clark, B. R. (2004). Delineating the character of the entrepreneurial university. Higher Education Policy, 17, $355-370$.

Covin J. G., \& Slevin, D. (1989). Corporate entrepreneurship and performance. Strategic Management Journal, $10,75-87$.

Covin J. G., \& Slevin, D. (1991). A conceptual model of entrepreneurship as a firm behavior. Entrepreneurship Theory and Practice, 16(1), 25-36.

Covin, J., \& Miles, M. P. (1999). Corporate entrepreneurship and the pursuit of competitive advantage. Entrepreneurship: Theory and Practice, Spring 1999, 47-63.

Covin, J. G., \& Slevin, D. (1988). The Influence of organization structure on the utility of an entrepreneurial top management style. Journal of Management Studies, 25(3), 217-259.

Covin, J. G., \& Slevin, D. (1989). Strategic management of small firms in hostile and benign environments. Strategic Management Journal, 10(1), 75-87.

Dess, G. G., Lumpkin, G. T., \& Covin, J. G. (1997). Entrepreneurial strategy making and firm performance: Tests of contingency and configurational models. Strategic Management Journal, 18(9), 677-695.

Dill, D. D. (1992). Academic Administration. The Enclopedia of Higher Education, 2, 1318-1329.

Doğan, B., \& Özdemirci, A. (2012). The Effect Of Business Owners'/Leaders' Cultural Values on The Strategic Behavior In Condition Of Crisis: A Research On Small Enterprises in Istanbul Chamber of Industry. International Journal of Business and Social Research, Maryland Institute of Research (MIR), 2(2), 20-32.

Doğramac1, İ. (2007). Türkiye'de ve Dünyada Yükseköğretim Yönetimi. Ankara: Meteksan A.Ş.

Ellis, R. J., \& Taylor, N. (1987). Specifying entrepreneurship. Frontiers of Entrepreneurship Research. Wellesley, MA: Babson College, 527-542.

Etzkowitz, H. (2004). The evolution of the entrepreneurial university. Int. J. Technology and Globalisation, 1(1), 64-77.

Gautam, V., \& Verma, V. (1997). Corporate entrepreneurship: changing perspectives. The Journal of Entrepreneurship, 6(2), 233-247.

Guth, W., \& Ginsberg, A. (1990). Guest editor's introduction: corporate entrepreneurship. Strategic Management Journal, 11(13), 5-13.

Hambrick, D. C., \& Mason, P. A. (1984). Upper echelons: The organization as a reflections of its top managers. The Academy of Management Review, 9(2), 193-206.

Hornsby J. S., Naffziger, D. W., Kuratko, D. F., \& Montagno, R. V. (1993). An integrative model of corporate entrepreneurship process. Entrepreneurship Theory and Practice, Winter, 29-37.

Ivar, B., \& Kogan, M. (2007). Organization and governance of universities. Higher Education Policy, 20 , 477-493.

Kanter, R. (1985). Supporting innovation and venture development in established companies. Journal of Business Venturing, 1(1) 47-60. http://dx.doi.org/10.1016/0883-9026(85)90006-0

Keller, G. (1983). Academic strategy: The Management Revolution in American Higher Education. Baltimore: The Johns Hopkins University Press.

Khandwalla, P. N. (1987). Generators of pioneering-innovative management: Some Indian evidence. Organization Studies, 8(1), 39-59.

Kotler, P., \& Murphy, P. (1981). Strategic Planning for Higher Education. Journal of Higher Education, 52(5), $470-489$.

Littunen, H. (2000). Entrepreneurship and the characteristics of the entrepreneurial personality. International Journal of Entrepreneurial Behaviour \& Research, 6(6), 295-309. http://dx.doi.org/10.1108/13552550010362741

Lumpkin, G. T., \& Dess, G. G. (1996). Clarifying the entrepreneurial orientation construct and linking it to performance. Academy of Management Review, 2(1), 135-172.

McClelland, D. C. (1961). The Achieving Society. New York: Collier-Mcmilan.

Miller, D. (1983). The correlates of entrepreneurship in three types of firms. Management Science, 29(7), 
770-791.

Miller, D. (1987). The structural and environmental correlates of business strategy. Strategic Management Journal, 8, 55-76.

Miller, D., \& Friesen, P. H. (1983). Strategy-making and environment: The third link. Strategic Management Journal, 4, 221-35.

Miller, D., \& Friesen, P. H. (1982). Innovation in conservative and entrepreneurial firms: Two models of strategic momentum. Strategic Management Journal, 3(1), 1-25.

Miller, D., Manfred F. R., Vries, K. D., \& Toulouse, J. M. (1982). Top executive locus of control and its relationship to strategy making. Structure and Environment Academy of Management Journal, 25(2), 237-253.

Miller, D., \& Toulouse, J. M. (1986). Chief executive personality and corporate strategy and structure in small firms. Management Science, 32(11), 1389-1409.

Naman, J. L., \& Slevin, D. P. (1993). Entrepreneurship and the concept of fit: A model and empirical tests. Strategic Management Journal, 14, 137-53.

Özdemirci, A. (2011). Corporate entrepreneurship and strategy process: A performance based research on Istanbul market, The Proceedings of 7th International Strategic Management Conference, Procedia. Social and Behavioral Sciences, 24, 611-626.

Popescu, M., \& Lache, S. (2009), Entrepreneurship in university. International Conference on Economic Engineering and Manufacturing Systems, 26-27.

Porter , M. E. (1980). Competitive Strategy. New York: The Free Press.

Roberts, E. B. (1980). New ventures for corporate growth. Harvard Business Review, 58(4), 134-142.

Rothaermel, F. T., Agung, S. D., \& Jiang, L. (2007). University entrepreneurship: A taxonomy of the literature. Industrial and Corporate Change, 16(4), 691-791.

Rotter, J. B. (1966). Generalized Expectations for Internal Versus External Control of Reinforcement. Psychological Monographs: General and Applied, 80(1), 1-27

Russell, R. D., \& Russell, C. J. (1992). Examination of the effects of organisational norms, organisational structure and environmental uncertainty on entrepreneurial strategy. Journal of Management, 18(4), 639-656.

Saruhan, Ş. C., \& Özdemirci, A. (2011). Bilim, Felsefe ve Metodoloji. Istanbul: Beta Yayıncılık.

Schollhammer, H. (1982). Internal corporate entrepreneurship. In C. Kent, D. Sexton \& K. Vesper (Eds.), Encyclopaedia of Entrepreneurship. Englewood Clipp, NJ: Prentice Hall.

Stevenson, H. H., \& Jarillo, J. C. (1990). A paradigm of entrepreneurship: Entrepreneurial Management. Strategic Management Journal, 11, 17-27.

Voich, D. (1995). Comparative empirical analysis of cultural values and perceptions of political economy issues. Westport. CT: Praeger.

Wally, S., \& Baum, J. R. (1994). Personal and structural determinants of the pace of strategic decision making. Academy of Management Journal, 37(4), 932-956.

Wan, Z. (2004). Competitive Strategy, Competitive Forces and Business Level Performance in the U.S. Wood Household Furniture Industry, Missisippi State University, Unpublished PhD. Dissertation, USA.

Zahra, S. A. (1991). Predictions and financial outcomes of corporate entrepreneurship: an explanatory study. Journal of Business Venturing, 6(4), 259-285. http://dx.doi.org/10.1016/0883-9026(91)90019-A

Zahra, S. (1993). Environment, corporate entrepreneurship and financial performance: A taxonomic approach. Journal of Business Venturing, 8(4), 319-340. http://dx.doi.org/10.1016/0883-9026(93)90003-N

Zahra, S., \& Garvis, D. M. (n.d.). International corporate entrepreneurship and firm performance: The moderating effect of international environmental hostility. Journal of Business Venturing, 15, 469-492. http://dx.doi.org/10.1016/S0883-9026(99)00036-1

Zahra, S. A. (1986). A canonical analysis of corporate entrepreneurship: Antecedents and impact on performance. Proceedings of National Academy of Management, 46, 71-75. 
Zahra, S. A., Jennings, D. F., \& Kuratko, D. F. (1999). The antecedents and consequences of firm-level entrepreneurship: The State of the field. Entrepreneurship Theory and Practice, 24(2), 45-66.

\section{Copyrights}

Copyright for this article is retained by the author(s), with first publication rights granted to the journal.

This is an open-access article distributed under the terms and conditions of the Creative Commons Attribution license (http://creativecommons.org/licenses/by/3.0/). 